How to Cite

Marhaeni, A., Kusuma, I., Dewi, N., \& Paramartha, A. (2019). Using performance assessment to empower students' learning ownership and promote achievement in EFL writing courses. International Journal of Humanities, Literature \& Arts, 2(1), 9-17. https://doi.org/10.31295/ijhla.v2n1.55

\title{
Using Performance Assessment to Empower Students' Learning Ownership and Promote Achievement in EFL Writing Courses
}

\author{
A.A.I.N. Marhaeni \\ Universitas Pendidikan Ganesha, Singaraja, Indonesia \\ Corresponding author email: ngurah_marhaeni@yahoo.com \\ I.P.I. Kusuma \\ Universitas Pendidikan Ganesha, Singaraja, Indonesia \\ N.L.P.E.S. Dewi \\ Universitas Pendidikan Ganesha, Singaraja, Indonesia \\ A.A.G.Y. Paramartha \\ Universitas Pendidikan Ganesha, Singaraja, Indonesia
}

\begin{abstract}
This study aims at investigating (1) To what extent performance assessment successfully fosters students' learning ownership and writing achievement and (2) Teachers' readiness related to the implementation of performance assessment in writing courses. This study was conducted using a mixed methods approach. Quantitative analysis of MANOVA was used to know the effect of performance assessment on students' learning ownership and writing achievement; while qualitative analysis was conducted for data of teacher readiness gathered using questionnaires and interviews. The subjects of the study were 32 EFL teachers and 82 students of Junior High Schools in Bali. Results of the analysis show that performance assessment significantly affects students' learning ownerships and writing competency; while teachers' readiness in implementing performance assessment largely depends on the availability of assessment instruments which are different from the traditional multiple choice type test.

Keywords---learning ownership, performance assessment, teachers' readiness, writing achievement.
\end{abstract}

\section{Introduction}

The release of Indonesian latest curriculum in 2013 has brought shifts into Indonesian practices. One of the shifts is on the implementation of educational assessment as an essential part of learning. The Indonesian Ministry of Education through the regulation established by Indonesian Ministry of Education and Culture number 104 Year 2014 chapter 2 verse 2, mandates Indonesian teachers to implement authentic assessments to assess students' learning in all subject matters, including English as a foreign language (EFL) courses which cover four major skills such as listening, speaking, reading, and writing.

Writing as one of the language skills is important to be learned. Harmer (1998), states that writing is important to be taught because of some reasons such as writing reinforces the students to acquire language, the process of writing helps the students to learn as they go along, and writing is appropriate for reflective activity instead of face to face communication. Glastonbury (2008), believes that a writing program is effective when it engages students and inspires critical thinking, collaborative dialogue, self-reflection, and evaluation. In writing, students have to work hard to force their imagination. At the time, they use their expression of thought, feeling, etc in written text. They also have to demonstrate language ability to facilitate communication in a proper written language.

ISSN 2632-9441

Received Jan 20, 2019 / Accepted Jun 18, 2019 / Published Jul 05, 2019 
In a classroom context, a writing program needs to be assessed. Assessment is very essential in all types of learning in all education in the world, including education in Indonesia. As explained by some scholars (e.g. O'Malley \& Pierce, 1996; Johnson \& Johnson, 2002; and Black et al., 2005), assessment is the activity which can help to learn and can give any comprehensive information to both teachers and students to improve the quality of the learning process they undergo. Moreover, without assessment, we cannot say what we have passed through as learning since we do not have any information as well as feedback which indicate we have learned something.

Apparently, through the implementation of Curriculum 2013, teachers are strongly expected to promote meaningful learning by providing real-world tasks to the students through the implementation of authentic assessment. By giving them real-world tasks, they will experience what the real world is at school as the small representation of larger society. In here, students are required to demonstrate the application of their knowledge and skills that they have learned.

Authentic assessment is a concept promoted by Wiggins (1990), whereby students are engaged in applying skills and knowledge to solve the real-world problems, giving the task a sense of authenticity. Moreover, Lund (1997), explains that assessment tasks are set in a meaningful context that provides connections between real-world experiences and school-based ideas. There are several kinds of authentic assessment that might be appropriate in a language learning context, such as performance assessment.

Performance assessment is used to describe any assessment procedure that involves either the observation of behavior in the real world or a simulation of a real-life activity - i.e. a performance of the ability being assessed, or the evaluation of the performance by raters (Weigle, 2002). With this characteristic, performance assessments should be used primarily to measure those learning outcomes in productive language skills which cannot be measured well by objective test items since tests are only intended for measuring students' knowledge in the language (Desheng \& Varghese, 2013). Further, Weigle (2002), argues that performance assessment differs from conventional paper-andpencil tests in the degree to which they represent or simulate behavior in the real world. In assessing writing, this will involve actual writing where the written product represents a performance of writing ability.

Research findings have revealed that performance assessment helps both teachers and students (Linn and Gronlund 1995; Shepard, 1995; Khattri, at al., 1995; and Abedi, 2010). Those studies explicate that a major benefit of performance assessment is that it can clearly communicate instructional goals that involve complex performances. Students involve in doing rather just showing that they know something. Besides, Shepard (1995), claimed that performance assessment brings positive effect both for teachers and students. For teachers, it helps them redirect instruction toward more challenging and appropriate learning goals. For students, it can help students to learn more. In addition, Khattri et al., (1995), reported that performance assessments affect learning as well as teaching. Students are more motivated to learn and are more engaged with project-based tasks than with other types of assignments. Teachers at the schools in our study that employ writing portfolios and literacy-based assessments also say students are developing better writing skills and habits (Suryasa et al., 2017, 2018, 2019; Djahimo et al., 2018).

The aforementioned statements indicate that writing processes together with performance assessment can empower student learning, especially in a language learning setting. Beside promoting writing achievement, performance assessment which is integrated into a writing program can also affect students' metacognitive development (Marhaeni, 2015). Considering that in doing a language performance like writing students have demonstrated complex cognitive and metacognitive tasks, this may also relate to the student's ownership of their writing process. Lakin (2007), views learning ownership as an important part of learning. It helps students to be independent thus being able to reflect upon their learning. By having learning ownership, students are able to identify their learning needs. Understanding learning needs then help them to find the best strategy to fulfill the needs in order to achieve the learning goals.

According to Milner-Bolotin (2001), ownership of learning is broken down into three interacting components. Those are finding a personal value (e.g. understanding how the knowledge and the skills developed in a learning process might be useful in other situations, outside the original learning environment); feeling in control (e.g. learner has an active role in making decisions); taking responsibility (e.g. learner is accountable for the process of learning as well as for its results). When all the three components overlap, learner reaches the highest levels of ownership. Marhaeni \& Artini (2014), reported that there is a need in Indonesian new school curriculum to apply performance assessment for not only development of language skills but also for those metacognitive aspects which support learning.

As performance assessment concepts and practices have just recently emphasized in Indonesian educational context, our concerns also involve teachers' readiness in implementing it. So far, a study on the readiness of Indonesian teachers in implementing performance assessment is hard to find. A survey has just revealed an aggregate result that teachers are ready to implement the new 2013 curriculum but not yet ready to implement authentic 
assessment (Marhaeni and Artini, 2014). While the argument is, empowering students cannot be done in cognitive aspects only but also their meta-cognitive aspects, and students' empowerment needs teachers' intervention in their learning, thus, based on the aforementioned rationale, teachers readiness in implementing performance assessment and the effect of performance assessment on students' writing competency and ownership of learning are important to be further studied and discussed (Hounhanou, 2018); Ruan, 2018; Dossoumou et al., 2018).

\section{Research Questions}

1) To what extent does performance assessment successfully foster students' learning ownership and writing achievement?

2) How is teachers' readiness in relation to the implementation of performance assessment in EFL writing courses?

\section{Research Methods}

This study used a mixed-methods approach of quantitative and qualitative research. Quantitative techniques were used in an experiment and the data were analyzed using Multivariate Analysis of Variance (MANOVA). The experiment used posttest-only control group design in which the independent variable was performance assessment $\left(\mathrm{X}_{1}\right)$ and the dependent variables were student learning ownership $\left(\mathrm{Y}_{1}\right)$, and writing achievement $\left(\mathrm{Y}_{2}\right)$. The experimental design is drawn below.

\begin{tabular}{lll}
$\mathrm{R}$ & $\mathrm{X}$ & $\mathrm{O}_{1}$ \\
$\mathrm{R}$ & & $\mathrm{O}_{2}$ \\
\hline
\end{tabular}

Fig. 1 Post-test Only Control Group Design

Description:

$\mathrm{R} \quad=$ Random

$\mathrm{X}=$ Experimental treatment

$\mathrm{O}_{1} \quad=$ Post-test Result Experimental Group

$\mathrm{O}_{2} \quad=$ Post-test Result of Control Group

The qualitative was used to know about teachers' readiness in implementing performance assessment in EFL writing classrooms, in which data were gathered through questionnaires and interviews. The data were collected by using Guttman Scales questionnaires of teachers' readiness to implement performance assessment; Likert Scale Questionnaires were used to measure students' learning ownership, and a writing task and a scoring rubric were used to collect data on students' writing achievement.

Data analysis was conducted in stages: Stage One was an analysis of the effect of performance assessment on students' learning ownership and writing achievement by using Multivariate Analysis of Variance (MANOVA) assisted by SPSS 20.0 for Windows. Stage Two was an analysis of teachers' readiness data from questionnaires and interviews which were analyzed qualitatively.

The subjects of this study were 32 EFL teachers and 82 students of Junior High Schools in Bali. Subjects selection of EFL teachers from four regencies in Bali province was based on multistage random sampling techniques; while students participating in the experiment were randomly selected from homogenous intact groups in a junior high school.

\section{Findings and Discussion}

\section{Findings}

Data about learning ownership was gathered at the end of the treatment. The data was collected by using questionnaires where the maximum score of these questionnaires was 365 while the minimum score was 73 . Then, the data showed that the maximum score of learning ownership in the experimental group was 324 while the minimum score was 294 . The data also showed that all students' scores were in the very high category as shown by $100 \%$. Meanwhile, the maximum score in the control group was 306 and the minimum score was 274 . Furthermore, 
only $90.24 \%$ of students' scores belonged to the very high category in this control group. The distribution of the data can be seen in the following table.

Table 1

Learning Ownership Distribution in Experimental and Control Group

\begin{tabular}{|c|c|c|c|c|c|}
\hline \multirow{2}{*}{ Score } & \multirow{2}{*}{ Qualifications } & \multicolumn{2}{|c|}{ Experiment } & \multicolumn{2}{|c|}{ Control } \\
\hline & & Fo & Percentage & Fo & Percentage \\
\hline $292 \leq X \leq 365$ & Very High & 41 & $100 \%$ & 37 & $90.24 \%$ \\
\hline $243 \leq X<292$ & High & 0 & $0.00 \%$ & 4 & $9.76 \%$ \\
\hline $195 \leq X<243$ & Sufficient & 0 & $0.00 \%$ & 0 & $0.00 \%$ \\
\hline $146 \leq X<195$ & Low & 0 & $0.00 \%$ & 0 & $0.00 \%$ \\
\hline $73 \leq X<146$ & Very Low & 0 & $0.00 \%$ & 0 & $0.00 \%$ \\
\hline Total & & & $100.0 \%$ & & $100.0 \%$ \\
\hline
\end{tabular}

Talking about students' achievement in writing courses, it was found that the minimum score in the experimental group was 76 while the maximum score was 98 . Moreover, $92.68 \%$ of students score belonged to the very high category. Meanwhile, the minimum score in the control group was 72 and the maximum score was 92 where 78.05 of students score were in the very high category. The details about this data can be seen in the following table.

Table 2

Learning Achievement Score in Experimental and Control Group

\begin{tabular}{cccccc}
\hline \multirow{2}{*}{ Score } & \multirow{2}{*}{ Qualifications } & \multicolumn{2}{c}{ Experiment } & \multicolumn{2}{c}{ Control } \\
\cline { 3 - 5 } & & Fo & Percentage & Fo & Percentage \\
\hline $80 \leq \mathrm{X} \leq 100$ & Very High & 38 & $92.68 \%$ & 32 & $78.05 \%$ \\
$67 \leq \mathrm{X}<80$ & High & 3 & $7.32 \%$ & 9 & $21.95 \%$ \\
$53 \leq \mathrm{X}<67$ & Sufficient & 0 & $0.00 \%$ & 0 & $0.00 \%$ \\
$40 \leq \mathrm{X}<53$ & Low & 0 & $0.00 \%$ & 0 & $0.00 \%$ \\
$20 \leq \mathrm{X}<40$ & Very Low & 0 & $0.00 \%$ & 0 & $0.00 \%$ \\
Total & & & $100.0 \%$ & & $100.0 \%$ \\
\hline
\end{tabular}

The data above was sufficient to be conducted into further analysis. Prerequisite tests were conducted before continuing into hypothesis testing. Since all prerequisite tests have been conducted and the values in each test have fulfilled the standard score required, thus hypothesis testing could be continued. The first, second, and third hypothesis tests were conducted using multivariate of variance test. The first and second hypotheses were tested using the Test of Between-Subjects Effects. The result can be seen in the following table.

Table 3

Result of Test of Between-Subjects Effects

\begin{tabular}{|c|c|c|c|c|c|c|}
\hline Source & $\begin{array}{c}\text { Dependent } \\
\text { Variable }\end{array}$ & $\begin{array}{l}\text { Type III Sum } \\
\text { of Squares }\end{array}$ & df & Mean Square & $\mathrm{F}$ & Sig. \\
\hline Corrected & Ownership & $12195.122^{a}$ & 1 & 12195.122 & 350.300 & .000 \\
\hline Model & Writing & $458.976^{b}$ & 1 & 458.976 & 16.459 & .000 \\
\hline \multirow[t]{2}{*}{ Intercept } & Ownership & 7260487.805 & 1 & 7260487.805 & 208554.314 & .000 \\
\hline & Writing & 593130.195 & 1 & 593130.195 & 21270.304 & .000 \\
\hline \multirow[t]{2}{*}{ Group } & Ownership & 12195.122 & 1 & 12195.122 & 350.300 & .000 \\
\hline & Writing & 458.976 & 1 & 458.976 & 16.459 & .000 \\
\hline \multirow[t]{2}{*}{ Error } & Ownership & 2785.073 & 80 & 34.813 & & \\
\hline & Writing & 2230.829 & 80 & 27.885 & & \\
\hline \multirow[t]{2}{*}{ Total } & Ownership & 7275468.000 & 82 & & & \\
\hline & Writing & 595820.000 & 82 & & & \\
\hline Corrected & Ownership & 14980.195 & 81 & & & \\
\hline Total & Writing & 2689.805 & 81 & & & \\
\hline
\end{tabular}


a. $\mathrm{R}$ Squared $=.814$ (Adjusted R Squared $=.812$ )

b. $\mathrm{R}$ Squared $=.171$ (Adjusted R Squared $=.160)$

The effect of performance assessment on learning ownership $\left(\mathrm{Y}_{1}\right)$ is shown by $\mathrm{F}$ that is 350.300 with a significance of 0.000. Thus the null hypothesis which states that there is no effect on learning ownership caused by performance assessment is rejected. The analysis shows that there is a significant effect on learning ownership $\left(\mathrm{Y}_{1}\right)$ caused by performance assessment.

On the other hand, the effect of performance assessment on writing competency $\left(\mathrm{Y}_{2}\right)$ is shown by $\mathrm{F}$ that is 16.459 with a significance of 0.000 . Thus, the null hypothesis which states that there is no effect of performance assessment on writing competency is rejected. Thereby, there is an effect on writing competency which caused by performance assessment, and the effect is significant.

The third hypothesis in this study was tested using Multivariate Tests. The result can be seen in the following table.

Table 4

Result of Multivariate Test

\begin{tabular}{|c|c|c|c|c|c|c|}
\hline & Effect & Value & $\mathrm{F}$ & $\begin{array}{c}\text { Hypothesis } \\
\text { df }\end{array}$ & $\begin{array}{l}\text { Error } \\
\text { df }\end{array}$ & Sig. \\
\hline \multirow{4}{*}{ Intercept } & Pillai's Trace & 1.000 & $104821.217^{\mathrm{b}}$ & 2.000 & 79.000 & .000 \\
\hline & Wilks' Lambda & .000 & $104821.217^{\mathrm{b}}$ & 2.000 & 79.000 & .000 \\
\hline & Hotelling's Trace & 2653.702 & $104821.217^{\mathrm{b}}$ & 2.000 & 79.000 & .000 \\
\hline & Roy's Largest Root & 2653.702 & $104821.217^{b}$ & 2.000 & 79.000 & .000 \\
\hline \multirow[t]{4}{*}{ Groups } & Pillai's Trace & .823 & $183.613^{\mathrm{b}}$ & 2.000 & 79.000 & .000 \\
\hline & Wilks' Lambda & .177 & $183.613^{\mathrm{b}}$ & 2.000 & 79.000 & .000 \\
\hline & Hotelling's Trace & 4.648 & $183.613^{\mathrm{b}}$ & 2.000 & 79.000 & .000 \\
\hline & Roy's Largest Root & 4.648 & $183.613^{\mathrm{b}}$ & 2.000 & 79.000 & .000 \\
\hline
\end{tabular}

a. Design: Intercept + Group

b. Exact statistic

The analysis shows that the significance values of Pillai's Trace, Wilks' Lambda, Hotteling's Trace, Roy's Largest Root are 0.000 . This value is lower than 0.05 , it means that there is a simultaneous significant effect of performance assessment on students' learning ownership and writing competency.

Besides collecting the data about learning ownership and performance assessment, the data about teachers' readiness in implementing performance assessment in writing courses were also collected by using questionnaires. The data shows that $85 \%$ of teachers understood how to assess students' performance in writing courses while $15 \%$ did not know about it. Then, $90 \%$ of teachers knew how to implement performance assessment including the steps in implementing this assessment while $10 \%$ did not understand how to implement this kind of assessment. Somehow, $50 \%$ of teachers had performance assessment instruments while another 50\% did not have it. Moreover, 58\% of teachers stated that they were ready to implement performance assessment in writing course while $41 \%$ of teachers were not ready yet. Finally, 59\% of teachers stated that they always implemented performance assessment in writing class while $41 \%$ of teachers did not. The summary of the data could be seen in the following table.

Table 5

Teachers' Readiness in Implementing Performance Assessment

\begin{tabular}{llcc}
\hline \multirow{2}{*}{ No } & \multicolumn{1}{c}{ Statements } & \multicolumn{2}{c}{ Responses } \\
\cline { 3 - 4 } & \multicolumn{1}{c}{ Yes (\%) } & No (\%) \\
\hline 1. & I understand how to assess students' performance in writing courses & 85 & 15 \\
2. & $\quad$ I understand how to implement performance assessment in writing & 90 & 10 \\
& & & 50 \\
3. courses & I have performance assessment instruments & 50 & 50 \\
4. & I am ready to implement performance assessment in writing courses & 58 & 41 \\
5. & I always implement performance assessment in my writing class & 59 & 41 \\
\hline
\end{tabular}


In supporting the data above, the interview was conducted to several potential teachers which would give any comprehensive testimonies related to the data being observed. During this interview, they stated that they knew how to assess students' performance as well as implementing performance assessment in writing courses because they got this knowledge when they were students or from some seminars and workshops they have attended while those who stated that they did not have this knowledge was because they got very limited knowledge about them when they were students. Then, most teachers stated that not all teachers had performance assessment instruments such as prompt, scoring rubrics, self-assessment, etc since the government did not mainly provide these instruments to teachers. They often developed these instruments by themselves where they mostly adapted the instruments they got from the internet or books. Those limited knowledge and instruments then became the reasons that some of them were not ready in implementing performance assessment in writing courses.

\section{Discussion}

Talking about implementing performance assessment as a kind of assessment in writing courses, teachers need to know about the effectiveness of the implementation as considerations in implementing them someday. Even, teachers need any information on which assessment can motivate students in learning. By having the empirical evidence, teachers can be well motivated to choose performance assessment as one of the main assessments in writing courses.

The first hypothesis testing in the conducted experiment reveals that there is a significant effect of performance assessment on learning ownership. As Shepard (1995), has revealed in her research, by implementing performance assessment the teachers were able to redirect their classroom instructions and creating more challenging and meaningful learning goals. When the learning outcomes are meaningful for the students, they will be more motivated to learn.

One of the characteristics of authentic assessment is open-ended. Open-ended assessment tasks not only prompted teachers to teach differently and to be creative, but criteria were made explicit, and children learned more. Thus, as performance assessment can also be regarded as creative instructions and as a creative authentic assessment where the teachers must be creative in developing the task and the task itself may require the students to put their creativity in accomplishing it. Thus, it has the potential to help teachers and students to create more meaningful learning outcomes. As stated by Vasudevan (2013), creativity is vital in developing the learning process and motivates the students to be engaged in the learning process itself. Therefore, the implementation of performance assessment encourages students to engage in the learning process and have the chance to monitor their own progress and problems in learning. In order to help students to be that independent, teachers need to give open-ended tasks in which students have the opportunity to engage and take decisions upon their learning. When students engage in the learning process they will involve in understanding and investing in their own growth. It empowers and equips students with the understanding of where they need to go as learners and how to get there (Berger et al., 2014; Lakin, 2007).

The ability to monitor own progress, problems, and goals in learning are the characteristics of learning ownership. To support this statement, Lakin (2007), states that learning ownership fosters learners to be independent who can reflect upon their learning and identify their emerging learning needs. Similarly, Jones (2005), states that when learners know and understand their ability, need, and aim of learning,

One of the characteristics of performance assessment is that it provides opportunities for students to reflect upon their own learning through self-assess their language performance. By doing self-reflection upon their learning, students can view their learning experiences from different perspectives. It also helps the students to develop positive attitudes such as open-mindedness, whole-heartedness, and responsibility. Doing a self-reflection is an integral part of performance assessment. When students own their learning they also will show the ability to identify their learning goals. As stated by Berger et al., (2014), student' learning ownership transfers the ownership of meeting objectives from the teacher to the students. Students understand and work toward learning goals. The students become the main actor in assessing and improving his or her own learning. Tangible learning goals help students define what they are learning and why they are learning it, enabling them to monitor their progress toward the learning goals and develop metacognitive skills. To be able to assess their progress toward meeting their learning goals, students need to have the chance to monitor and check their progress along the way. Therefore, performance assessment can trigger the development of students' learning ownership. The quality of learning will improve as students develop ownership of their learning (Jones, 2005; Olusegun, 2015). 
Furthermore, hypothesis testing has proved that performance assessment cannot only foster students' learning ownership but also students' English writing achievement. As shown by this study that performance assessment gives a significant effect on students' writing competency.

In this study, performance assessment was implemented as an integral part of the writing process. The assessment procedures were created in line with the writing process and the students followed the process in order to produce the written products. The process consisted of prewriting, drafting, revising, proofreading, and publishing. During the prewriting process, the students were given some prompts to be used to jot down their ideas and make an outline. During the experiment, the students worked on writing two types of writing namely descriptive text and recount text. For the descriptive text, the prompt was in the form of a pyramid method while for the recount text, the prompt was in the form of a spider web. By using the prompts students could make an outline for the writing. During the drafting, students developed their outline into more specific details.

In order to develop rich and meaningful writing, the students were encouraged to use different resources. They used the internet, books, magazines, etc, to find examples or other related information. The next step was revising. The purpose of revising was to make the writing better. Revising possesses the greatest potential for learning as students can learn their mistakes by discovering the mistakes themselves or from the help of others (Sundem, 2006). Through revising, students tried to check their own understanding as well as a misunderstanding by discovering the mistakes they made in their own writings as well as others'. This activity was expected to make learning meaningful for them. The next process was proofreading. The purpose was to make sure that the piece is more acceptable based on a certain degree of convention. During the treatment, proofreading was done first by the writer, and then by the peer. To guide the students during the proofreading process, proofreading checklists were provided. The proofreading guide helped the students to check whether the writer possessed the expected criteria or not.

Performance assessment was integrated into the writing processes above. On every step of writing, students' works were assessed and given feedback for further process. On the other hand, the students were also encouraged to self-assess their own works. Some writing checklists were provided at hands such as Content Assessment Forms, Grammar Checkers, and Mechanics Checkers. By responding to the questions or statements on the self-assessment instruments students had the chance to think about their thinking; to think whether they understood the concept being taught or not. Self-assessment also helped the students to analyze why they did not understand the concept or what were the problems that made them having difficulties in learning. Self-assessment was also used to help the students checking their writing, whether their writing had fulfilled the expected criteria or not. When the writing had not met the expected criteria, they had to revise the writing. This activity helped the students to work based on standards and goals, and therefore their writing products closely resembled the expected criteria. By having such critical ability to judge their writing, the students writing performance could be improved (Andrade \& Boulay, 2003).

Paris \& Ayres (1994), stated that students who are independent are not reluctant to use available resources when they encounter problems and solve their problems independently. During the research, it was observed that students in the experimental groups were more active in using available resources to support their learning. Some of them bring some related books to school in order to help them to write, while others actively use their internet to seek for more information or explanations when needed. They were also conditioned to use the dictionary to help them cope with difficult words or terms. At the same time, they were also given the necessary time for the activities. Therefore, the final products of their writing were varied in term of ideas and were generally more sophisticated.

The power of performance assessment upon learning in EFL setting as explained above has also been proven by its significant simultaneous effect on students' learning ownership and writing competency. This proof that performance assessment is able to foster metacognitive aspects like learning ownership. Students' learning ownership develops because continuous exercises on self-assess and reflection are very highly facilitated. At the same time, performance assessment also promotes academic achievement, like, in this case, students' English writing competency. The process of writing in which performance assessment is integrated as explained above provides exercises for students to develop writing skills over time, progressing time by time until writing competency is built within those students.

In addition to the results of the experiment above, teachers' readiness in implementing performance assessment is also worth studying. Teacher readiness in implementing an instructional program is really needed since the program will not run well if the person who will conduct is not ready to implement it. Data of the questionnaire reveals that teachers knew how to assess the students' performance in writing skill which is very important for teachers to know. If teachers do not know how to assess students' performance, possibly teachers will implement inappropriate activity and even inappropriate assessment for the students. Of course, this is not something we expect from our education to happen. As stated by Iyer (2013), the duty of teachers is helping students to perceive the information and transform it into knowledge and to wisdom. Supporting this statement, Jalaludin et al., (2013), state that teachers must be the one who influences learning and motivation to learn to the students. Thus, if the teachers do not know how to teach 
writing skill, how could they help the students to perceive the information and motivate to learn. Moreover, teachers knew how to implement performance assessment. A good assessment program cannot be maintained well if teachers do not have any knowledge on the implementation of it. Thus, courses about practical assessment are necessary for prospective teachers in the order they know which kind of assessment should be implemented and how to implement it.

Unfortunately, not all teachers had performance assessment instruments which could be implemented in writing courses. Further analysis through interviews revealed that the teachers found it difficult to get appropriate instruments like writing assessment rubrics and also various writing checklists. Textbooks and teachers' books rarely include such sample instruments. Additionally, they also said that making rubrics and checklists are much more difficult than writing a multiple choice item. A long lasting tradition which emphasized on objective type tests in our education has contributed to this incapacity of teachers.

\section{Conclusion}

Based on the results of the data analysis and the discussion, it can be concluded performance assessment in EFL writing courses has a good potential to help to foster metacognitive ability and promote writing competency. Performance assessment has to be integrated into the writing process the students have to do to achieve those effects. Performance assessment works well in process-based learning like in language learning, because characteristics of performance assessment such as on-going, self-assess and reflection can be well instituted during the writing processes.

The success in implementing performance assessment in language classrooms also depends on teachers' readiness to implement it. The study shows that teachers' readiness depends largely on the availability of resources especially assessment instruments such as rubrics and checklists. This challenge becomes more serious because most teachers do not have the knowledge and experience to create such performance assessment instruments. Therefore, further research needs to be conducted to focus on the development of performance assessment instruments related to the characteristics of the language skills learned or to be assessed

\section{References}

Abedi, J. (2010). Performance assessments for English language learners. California: Stanford Center. Avalaible at https://edpolicy. stanford. edu/sites/default/files/events/materials/2011-06-linked-learning-performance-basedassessment. pdf (accessed 24 october 2015).

Anabokay, Y., \& Suryasa, I. W. (2019). TEFL Methods in Indonesia. International Journal of Linguistics, Literature and Culture, 5(2), 13-24. https://doi.org/10.21744/ijllc.v5n2.612

Andrade, H. G., \& Boulay, B. A. (2003). Role of rubric-referenced self-assessment in learning to write. The Journal of Educational Research, 97(1), 21-30. https://doi.org/10.1080/00220670309596625

Bada, S. O., \& Olusegun, S. (2015). Constructivism learning theory: A paradigm for teaching and learning. Journal of Research \& Method in Education, 5(6), 66-70.

Berger, R., Rugen, L., Woodfin, L., \& Education, E. L. (2014). Leaders of their own learning: Transforming schools through student-engaged assessment. John Wiley \& Sons.

Black, P., Harrison, C., Hodgen, J., Marshall, B., \& Serret, N. (2010). Validity in teachers' summative assessments. Assessment in Education: Principles, Policy \& Practice, 17(2), 215-232. https://doi.org/10.1080/09695941003696016

Desheng, C., \& Varghese, A. (2013). Testing and evaluation of language skills. IOSR Journal of Research \& Method in Education (IOSR-JRME) e-ISSN, 2320-7388.

Djahimo, S., Bili Bora, D., \& Huan, E. (2018). Student anxiety and their speaking performance: teaching EFL to Indonesian student. International Journal of Social Sciences and Humanities, 2(3), 187-195. https://doi.org/10.29332/ijssh.v2n3.235

Dossoumou, A. M., Mehouenou, M. S., \& Koukpossi, A. O. (2018). Appraising the impacts of cohesion and coherence in Benin SS3 EFL learners' writing productions. International Journal of Linguistics, Literature and Culture, 4(5), 41-54. https://doi.org/10.21744/ijllc.v4n5.293

Englot, D. J., Glastonbury, C. M., \& Larson, P. S. (2011). Abnormal T2-weighted MRI signal surrounding leads in a subset of deep brain stimulation patients. Stereotactic and functional neurosurgery, 89(5), 311-317.

Harmer, J. (1983). The practice of English language teaching. Longman, 1560 Broadway, New York, NY 10036. 
Hounhanou, A. V. (2018). Evaluating Benin EFL Learners Writing Composition during Final Exam. International Journal of Linguistics, Literature and Culture, 4(2), 9-23.

Iyer, R. B. (2013). Value-based education: Professional development vital towards effective integration. IOSR Journal of research and method in education, $1(1)$.

Jalaluddin, I., Yamat, H., \& Yunus, M. M. (2013). ESL writing self-efficacy: Contribution to ESL writing skills development. IOSR Journal of Research \& Method in Education, 2(1), 37-47.

Johnson, D. W., \& Johnson, R. T. (2002). Meaningful assessment: A manageable and cooperative process. Pearson College Division.

Jones, C. A. (2005). Assessment for learning.

Khattri, N., Reeve, A. L., \& Kane, M. B. (2012). Principles and practices of performance assessment. Routledge. https://doi.org/10.4324/9780203053836

Lakin, L. (2007). Science education students taking ownership of their learning.

Linn, R. L. (85). Gronlund, NE (1995). Measurement and assess-ment in teaching Englewood Cliffs.

Lund, J. (1997). Authentic assessment: Its development \& applications. Journal of Physical Education, Recreation \& Dance, 68(7), 25-28.

Marhaeni, A. A. I. N. (2015). Asesmen autentik dan pendidikan bermakna: implementasi kurikulum 2013. JPI (Jurnal Pendidikan Indonesia), 4(1).

Marhaeni, A. A. I. N., \& Dantes, N. (2014). Toward Authentic Language Assessment: A Case in Indonesian EFL Classrooms. In Official Conference Proceedings of the European Conference on Language Learning 2014.

Milner-Bolotin, M. (2001). The effects of topic choice in project-based instruction on undergraduate physical science students' interest, ownership, and motivation. University of Texas at Austin.

O'malley, J. M., \& Pierce, L. V. (1996). Authentic assessment for English language learners: Practical approaches for teachers. New York: Addison-Wesley Publishing Company.

Paris, S. G., \& Ayres, L. R. (1994). Becoming reflective students and teachers with portfolios and authentic assessment. American Psychological Association.

Ruan, X. (2018). Engagement and negotiation: Exploring a tertiary female EFL teacher's professional agency in her career development in P.R. China. International Journal of Linguistics, Literature and Culture, 4(3), 46-63.

Shepard, L. A. (1995). Using Assessment to Improve Learning. Educational Leadership, 52(5), 38-43.

Sundem, G. (2006). Improving Student Writing Skills: All Grades. Teacher Created Materials.

Suryasa, I. W., Prayoga, I. G. P. A., \& Werdistira, I. W. A. (2017). An analysis of students motivation toward English learning as second language among students in Pritchard English academy (PEACE). International Journal of Social Sciences and Humanities, 1(2), 43-50. https://doi.org/10.29332/ijssh.v1n2.36

Suryasa, I. W., Prayoga, I. G. P. A., \& Werdistira, I. W. A. (2018). Attitudes toward the use of internet for students. International Journal of Physical Sciences and Engineering, 2(2), 32-38. https://doi.org/10.29332/ijpse.v2n2.141

Vasudevan, H. (2010). The Influence of Teachers' Creativity, Attitude and Commitment on Students' Proficiency of the English Language (Doctoral dissertation, Jabatan Dasar dan Strategi Perniagaan, Fakulti Perniagaan dan Perakaunan, Universiti Malaya).

Weigle, S. C. (2007). Teaching writing teachers about assessment. Journal of Second Language Writing, 16(3), 194209.

Wiggins, G. (1990). The case for authentic assessment. Practical assessment, research \& evaluation, 2(2), 1-6. 